\title{
Effect of Woody Debris Abundance on Daytime Refuge Use by Cotton Mice
}

\author{
Travis M. Hinkelman ${ }^{1,2, *}$ and Susan C. Loeb ${ }^{3}$
}

\begin{abstract}
Daytime refuges are important to nocturnal rodents for protection from predators and environmental extremes. Because refuges of forest-dwelling rodents are often associated with woody debris, we examined refuge use by 37 radio-collared Peromyscus gossypinus (cotton mice) in experimental plots with different levels of woody debris. Treatment plots had six times $\left(\approx 60 \mathrm{~m}^{3} / \mathrm{ha}\right)$ the volume of woody debris as control plots $\left(\approx 10 \mathrm{~m}^{3} / \mathrm{ha}\right)$. Of 247 refuges, 159 were in rotting stumps $(64 \%), 32$ were in root boles $(13 \%), 19$ were in brush piles $(8 \%)$, and 16 were in logs $(6 \%) ; 10$ refuges could not be identified. Stumps were the most common refuge type in both treatments, but the distribution of refuge types was significantly different between treatment and control plots. Root boles and brush piles were used more on treatment plots than on control plots, and logs were used more on control plots than on treatment plots. Refuge type and vegetation cover were the best predictors of refuge use by cotton mice; root bole refuges and refuges with less vegetation cover received greater-than-expected use by mice. Abundant refuges, particularly root boles, may improve habitat quality for cotton mice in southeastern pine forests.
\end{abstract}

\section{Introduction}

Daytime refuges are important to nocturnal rodents for protection from environmental extremes, predator avoidance, and rearing young (Frank and Layne 1992). In the absence of large burrowing vertebrates such as Gopherus polyphemus Daudin (Gopher Tortoise) or prominent physical structures such as rock piles, refuges of forest-dwelling rodents are frequently associated with woody debris (McCay 2000).

In the southeastern United States, forest management practices (e.g., short harvest rotations) and a humid climate result in low volumes of woody debris (McCay et al. 2002). The relative scarcity of woody debris, large burrows, and rock structures in managed Pinus spp. (pine) stands (McCay 2000, McCay et al. 2002) suggests that refuges may function as a limiting factor for rodents in pine forests in the Southeast. Although woody debris is a resource that is amenable to management, little is known about the relationship between woody debris abundance and refuge use by rodents (Loeb 1996).

Peromyscus gossypinus LeConte (cotton mouse) is one of the most abundant terrestrial rodents in southeastern pine forests (Clark and Durden 2002,

\footnotetext{
${ }^{1}$ Department of Forestry and Natural Resources, Clemson University, Clemson, SC 29634. ${ }^{2}$ Current address - School of Biological Sciences, University of Nebraska, Lincoln, NE 68588. ${ }^{3}$ United States Forest Service, Southern Research Station, Department of Forestry and Natural Resources, Clemson University, Clemson, SC 29634. ${ }^{*}$ Corresponding author - think@bigred.unl.edu.
} 
Loeb 1999, Mengak and Guynn 2003). Further, in managed pine stands in South Carolina, cotton mouse abundance is positively associated with woody debris abundance (Loeb 1999), and 92\% of day refuges of cotton mice are associated with woody debris (McCay 2000). The association with woody debris and relatively high abundance makes the cotton mouse an important species in which to investigate the relationship between woody debris abundance and refuge use by rodents in southeastern pine forests.

If increasing woody debris increases the number of available refuges, competitive interactions may be reduced (Loeb 1996). Cotton mice use many refuges over a short period of time (Frank and Layne 1992, McCay 2000), and thus, increasing the availability of refuges may reduce constraints associated with trade-offs in the costs (e.g., parasite infestation) and benefits (e.g., site familiarity) of refuge fidelity, and the costs (e.g., predation risk) and benefits (e.g., proximity to food) of refuge switching (Banks et al. 2000, Lewis 1995, Norrdahl and Korpimäki 1998). Abundant refuges may also permit greater selectivity by mice for refuge attributes such as type and size (Frank and Layne 1992, Hall and Morrison 1997, McCay 2000, Wolff and Hurlbutt 1982) and attributes of the refuge neighborhood such as vegetation cover (Kalcounis-Rüppell and Millar 2002, Morzillo et al. 2003, Wagner et al. 2000).

The objectives of this study were to: (1) identify refuge types used by cotton mice and determine if the distribution of types differed between areas of low and high woody debris, (2) test if fidelity differed between areas of low and high woody debris, and (3) model refuge selection as a function of refuge attributes and the refuge neighborhood.

\section{Methods}

\section{Study site and experimental design}

This study was conducted on the Savannah River Site (SRS) from May to September 2002 and February to September 2003. The SRS is a 78,000-ha National Environmental Research Park in the upper Coastal Plain of South Carolina located in Aiken, Allendale, and Barnwell counties. Study plots consisted of six 9.3-ha plots situated in 50-yr old Pinus Taeda Linnaeus (loblolly pine) stands. Soils were sandy and well drained (Workman and McLeod 1990).

Although loblolly pine was the dominant overstory species, Quercus spp. (oak), Carya spp. (hickory), Liquidambar styraciflua Linnaeus (sweetgum), and Morella cerifera Linnaeus (wax myrtle) were also found throughout the plots in the overstory and midstory. Numerically dominant understory species included Toxicodendron pubescens P. Miller (poison oak), Anthemis cotula Linnaeus (dog fennel), and Lespedeza spp. (lespedeza).

In August 2001, trees on the three treatment plots were felled with feller-bunchers to increase log volumes to approximately six times the level on the three control plots. Feller-bunchers typically cut trees at the base creating stumps and $\log$ s, but occasionally trees were felled by uprooting, 
which produced root boles and logs. Both methods of felling trees generated an influx of fine woody debris. The newly created stumps and logs were generally sound, i.e., in an early stage of decay. About a quarter of the trees on the control plots were girdled with a chainsaw in spring 2001 so that the basal area of live trees on all six plots was about $15 \mathrm{~m}^{2} / \mathrm{ha}$. Treatment activities (i.e., log and snag creation) yielded open stands with well-developed understory vegetation. The control and treatment plots were paired, which yielded three blocks of two treatments. All 6 plots were burned in January to March of 2000 or 2001 prior to the implementation of the treatments.

Percent volume of understory vegetation (below a height of $3 \mathrm{~m}$ ) was estimated during the growing season of each year within twenty-five 0.04-ha sampling plots arranged on each of the six study plots in a 5-by-5 grid with $50-\mathrm{m}$ spacing. The length and diameter at midpoint of all $\operatorname{logs} \geq 10 \mathrm{~cm}$ in diameter was measured within eight randomly selected 0.25 -ha subplots on each of the control and six randomly selected 0.25 -ha subplots on the three treatment plots. Log volume was estimated with the formula for the volume of a cylinder ( $\mathrm{V}=\pi^{*} \mathrm{r}^{2} *$ length), and the total volume of logs was summed for each subplot. A year was divided into growing (1 April to 30 September) and non-growing (1 October to $31 \mathrm{March}$ ) seasons, which hereafter will be referred to as summer and winter, respectively.

\section{Trapping}

An 8-by-8 trapping grid with 20 -m spacing was placed at the center of each plot. The grids were at least $50 \mathrm{~m}$ from the plot borders. One folding aluminum Sherman live trap $(7.5 \times 9.0 \times 25.5 \mathrm{~cm})$ was placed on the ground and in the nearest tree at each station (Loeb et al. 1999). Ground traps were baited with sunflower seeds to limit the attraction of Solenopsis wagneri Santschi (red imported fire ant), and tree traps were baited with peanut butter. Bimonthly trapping was conducted during the course of this study as part of a larger, long-term effort to monitor small-mammal populations within the plots. Trapping sessions spanned seven nights centered on the new moon phase. Additional trapping was conducted as time permitted to augment the number of cotton mice tracked.

Traps were checked in the early morning of every day of a trapping period. All captured animals were marked with ear tags, weighed, and identified by species, sex, age, and reproductive condition. Age of cotton mice was determined by a combination of pelage characteristics and mass (adult: $\geq 18 \mathrm{~g}$ ). An animal that was obviously in reproductive condition (e.g., descended testes) was recorded as an adult regardless of mass or pelage. All non-target captures were released without handling during the additional trapping periods.

\section{Radio-tracking}

Adult cotton mice weighing $\geq 20 \mathrm{~g}$ with at least one previous capture were selected for radio-tracking. The minimum-mass criterion was incorporated to 
limit the effect of the transmitter on the mouse's behavior, and the previouscapture criterion increased the likelihood that an individual was a resident of the plot. Individuals selected for transmitter attachment were anesthetized with a mixture of halothane and mineral oil and fitted with a radiocollar (M1420 transmitter, Advanced Telemetry Systems, Inc., Isanti, MN; MD-2C transmitter, Holohil Systems Ltd., Carp, ON, Canada). Transmitter attachment took less than 10 min per mouse. Radiocollars weighed about $1.3 \mathrm{~g}$ and averaged $5.4 \%$ of the mass of the radiotagged mice ( mean $=23.9 \mathrm{~g}$ ). Mice were held for $>1 \mathrm{hr}$ to recover from anesthesia and then released at the capture site.

One location was taken each day between sunrise and sunset for each collared mouse by homing with a TR-2 receiver and RA-2A two-element antenna (Telonics, Mesa, AZ). Cotton mice are not active on the surface during the day (McCay 2000). Tracking began on the day following transmitter attachment and continued for the life of the transmitter ( $\approx 30$ days $)$. When locating refuges, we attempted to limit any preconceived biases about refuge types by marking the location of the strongest signal even if no apparent refuge substrate was present.

We used the total number of locations per mouse as a measure of tracking effort. Refuge fidelity for each mouse was calculated as the number of locations divided by the number of refuges used. Thus, fidelity is an estimate of the average number of days that a mouse spent in a particular refuge whether they were consecutive or not. Fidelity is an attribute of the mouse, not the refuge.

\section{Characterizing refuges}

We recorded the type (stump, root bole, log, tree base, or brush pile) and measured the dimensions (e.g., diameter, length, height) of each refuge. To standardize refuge size across types, we selected one dimension for each refuge type to reflect the size of that refuge. We used diameter for logs and stumps, diameter at breast height ( $\mathrm{dbh}$ ) for tree bases, circumference for root boles, and depth for brush piles. (We use the term "tree base" to emphasize that all refuges in trees were located at the base of the tree.) We created a standardized continuous variable for refuge size (i.e., mean $=0$ and $\mathrm{SD}=1$ ) by subtracting the mean and dividing by the standard deviation for each selected dimension.

The structural cover surrounding each refuge (i.e., neighborhood) was characterized with nested sampling plots. Within a 4-m radius plot $\left(50 \mathrm{~m}^{2}\right)$ centered on the refuge, we recorded the dbh of all trees $\geq 5 \mathrm{~cm} \mathrm{dbh}$, the height and diameter of all stumps, and the length and diameter of the portions of $\operatorname{logs}$ that were within the sampling plot. Within a $1.78-\mathrm{m}$ radius plot $\left(10 \mathrm{~m}^{2}\right)$ nested in the larger sampling plot, we estimated the percent ground cover of grass, forbs, shrubs, bare ground, and litter. To represent structural cover at each refuge, we calculated total percent cover of ground vegetation (i.e., sum of grass, forb, and shrub cover), area of stumps, volume of logs, and basal area of trees. 


\section{Data analysis}

We tested for differences in the total number (summed across plots) of refuge types between treatment and control plots with a likelihood-ratio test (PROC FREQ; SAS Institute, Inc. 2000). We used mixed-model analysis of variance (ANOVA) to test for differences in log volume, understory vegetation, tracking effort, and refuge fidelity by treatment and season (PROC GLM; SAS Institute, Inc. 2000). The ANOVA follows a split-plot design with three blocks, two treatments, two years or three seasons, and sub-samples comprised of either log subplots, vegetation sampling plots, or individual mice. Variables were logarithmically transformed to satisfy the assumptions of the ANOVA.

Refuge selection was modeled using negative binomial (NB) regression. Although Poisson distributions are typically used to model counts of animal locations (Millspaugh et al. 2006), our data exhibited overdispersion, indicating that NB regression was more appropriate than Poisson regression. NB regression models the probability of refuge use and circumvents the need to classify refuge sites as either used or unused as in logistic regression (Keating and Cherry 2004, Millspaugh et al. 2006). The modeling approach treated the data as survey observations rather than imposing any specific experimental-design constraints. The refuge was the experimental unit for the NB regression analysis.

The logarithm of the number of locations for a refuge was modeled as a linear combination of refuge, neighborhood, and plot variables. Refuge variables (type and size) described the refuge, neighborhood variables described the area surrounding the refuge, and plot variables (treatment and block) described the plot where the refuge was located. The number of locations for a refuge was log-linked to the expected number of locations for a refuge as an offset term (Erickson et al. 2001). For example, if we obtained 50 locations for a plot with 25 refuges, then the expected number of locations for each refuge on that plot was two. No selection would be inferred for any refuges on that plot with two locations.

To identify significant predictors of selection, we used a backward elimination procedure based on likelihood-ratio statistics for Type III analysis; no interaction terms were included in the model. For the variables included in the final model, pair-wise comparisons of parameter estimates were examined with linear contrasts. NB regression analyses were conducted with PROC GENMOD (SAS Institute, Inc. 2000).

\section{Results}

Log volume was significantly different between treatment and control plots $(F=20.94, d . f .=1, \mathrm{P}=0.0446)$, but not between years $(F=2.43, d . f .=$ $1, \mathrm{P}=0.1941)$. Log volumes were approximately $6 \mathrm{x}$ greater on treatment plots than on control plots (Table 1$)$. Understory vegetation varied significantly by year $(F=38.07, d . f .=1, \mathrm{P}=0.0035)$, but not by treatment $(F=$ 0.03 , d.f. $=1, \mathrm{P}=0.8775)$. Understory vegetation increased by about $50 \%$ from 2002 to 2003 (Table 1). 
The number of cotton mouse captures per trapping period per plot was similar between treatment and control plots with $1.4 \pm 0.4(\mathrm{sE})$ and $2.1 \pm 0.6$ captures, respectively, on control and treatment plots in 2002, and $4.4 \pm 1.8$ and $4.8 \pm 0.8$ captures, respectively, on control and treatment plots in 2003 . A total of 37 cotton mice were fitted with radiocollars; 9 individuals wore 2 collars. The number of telemetry locations for each mouse ranged from 1 to 44 because of slipped collars, transmitter failure, predation, and the tracking schedule. To limit the effect of unequal tracking effort, we excluded the 7 mice with $<9$ locations from the analysis of tracking effort and refuge fidelity.

We recorded an average of $21.01 \pm 0.87$ locations and $7.99 \pm 0.70$ refuges for collared mice. We documented one male on a control plot using 15 different refuges in a span of 3 months. The number of refuges observed for a mouse was positively correlated with the number of locations (Fig. 1). Tracking effort (i.e., number of locations) was not significantly different between treatment and control plots or among seasons $(\mathrm{P}>0.20)$, but there

Table 1. Mean $( \pm$ SE) log volume and understory vegetation on study plots by treatment and year.

\begin{tabular}{llcc} 
Year & Plot & $\log$ volume $\left(\mathrm{m}^{3} / \mathrm{ha}\right)$ & Understory vegetation (volume percent) \\
\hline 2002 & Control & $9.82 \pm 2.76$ & $19.09 \pm 3.88$ \\
& Treatment & $59.65 \pm 6.95$ & $19.60 \pm 2.51$ \\
2003 & Control & $9.61 \pm 2.48$ & $28.81 \pm 7.15$ \\
& Treatment & $57.34 \pm 6.79$ & $30.39 \pm 2.51$ \\
\hline
\end{tabular}

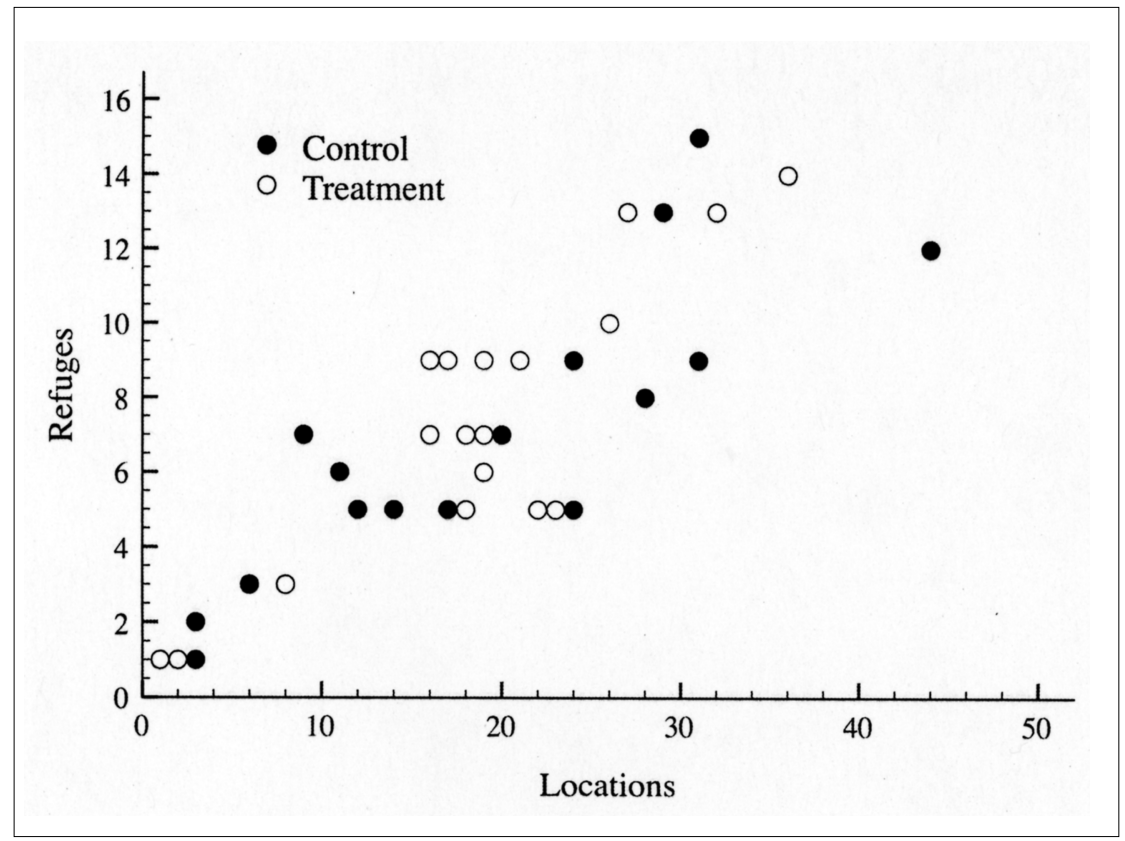

Figure 1. Number of refuges as a function of number of telemetry locations. 
was a significant treatment by season interaction $(F=14.26$, d.f. $=2, \mathrm{P}=$ $0.0294)$. There were no significant treatment, season, or treatment by season effects on refuge fidelity $(\mathrm{P}>0.10)$. However, the number of locations per refuge, i.e., fidelity, was considerably higher on treatment $(2.80 \pm 0.44)$ than control $(1.83 \pm 0.54)$ plots in summer 2002 , and fidelity was considerably higher on control $(3.15 \pm 0.25)$ than treatment $(2.25 \pm 0.13)$ plots in summer 2003 (Fig. 2).

Mice used rotted stumps $(\mathrm{N}=159)$, root boles $(\mathrm{N}=32)$, brush piles $(\mathrm{N}=19)$, $\operatorname{logs}(\mathrm{N}=16)$, and tree bases $(\mathrm{N}=11)$ as refuges. Another 10 refuges were recorded as "unidentified" and were most likely associated with shallow burrows (e.g., mole tunnels; McCay 2000). The 10 unidentified refuges, along with 4 of the 11 tree-base refuges that were in live trees, represented the only refuges that were not associated with woody debris. That is, 233 of 247 (94\%) refuges were associated with some form of woody debris. Several refuges were used by 2 different mice with the following breakdown by type: stumps $(\mathrm{N}=$ $15)$, brush piles $(\mathrm{N}=5)$, root boles $(\mathrm{N}=4)$, tree bases $(\mathrm{N}=2)$, and unknown $(\mathrm{N}=1)$. Only on 5 occasions were 2 mice found using the same refuge on the same day; all observations of joint nesting were during the winter.

Of the 247 refuges, 115 were on control plots and 132 were on treatment plots. Stumps were the most common refuge type in both control and treatment plots. The distribution of refuge types was significantly different between treatment and control plots $\left(G^{2}=29.71, d . f .=5, \mathrm{P}=0.0001\right)$. The differences were particularly evident in 3 types: root boles, brush piles, and

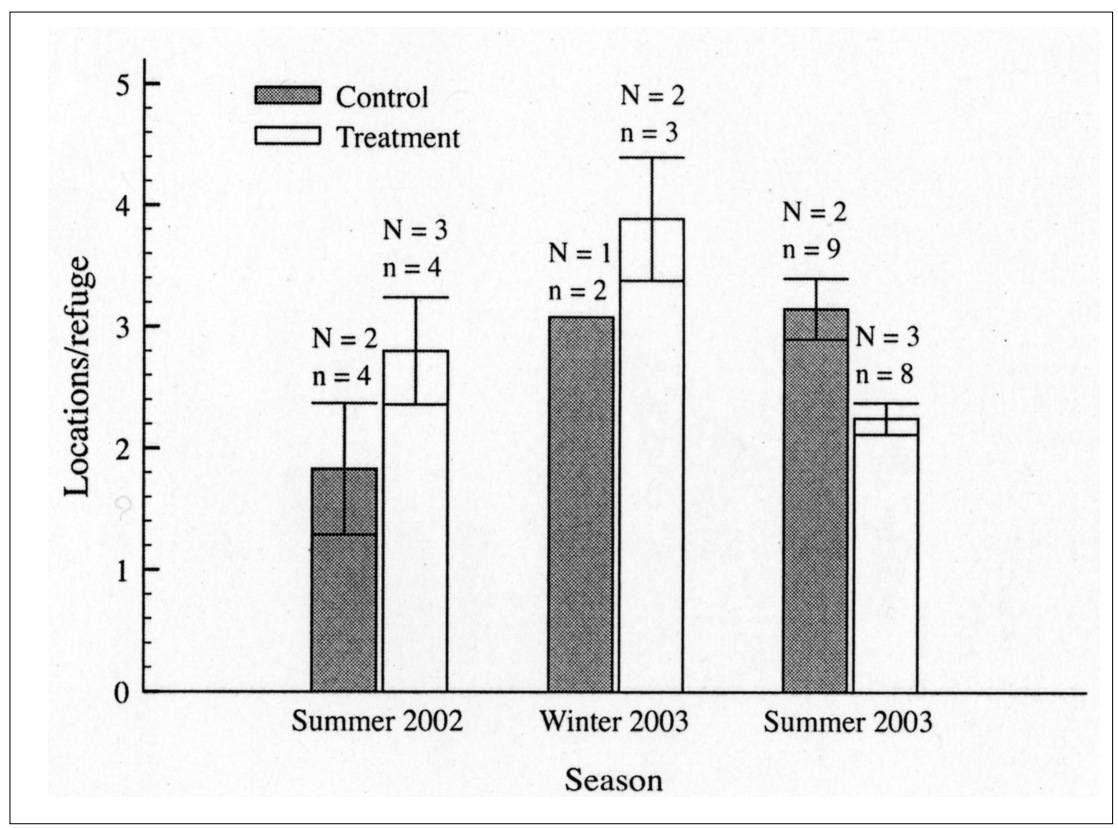

Figure 2. Mean $( \pm S E)$ locations per refuge on study plots by treatment and season $(\mathrm{N}=$ number of plots; $\mathrm{n}=$ number of mice $)$. 
logs. More root boles and brush piles were used on treatment plots than in control plots, whereas more log refuges were used on control plots than in treatment plots (Fig. 3).

The NB regression model yielded two significant main effects: vegetation cover $\left(\chi^{2}=4.10, d . f .=1, \mathrm{P}=0.043\right)$ and refuge type $\left(\chi^{2}=9.34\right.$, d.f. $=4$, $\mathrm{P}=0.053)$. Increasing vegetation cover decreased the likelihood that a refuge received greater than expected use. Linear contrasts for refuge type indicated that root bole refuges were significantly more likely to receive greater than expected use than log or stump refuges (Table 2).

\section{Discussion}

The main premise of this study was that refuges might be a limited resource for cotton mice in southeastern pine forests. However, capture data suggest that refuges were not limited because mouse density in both treatment and control plots was relatively low compared to previous years. Bimonthly trapping has been conducted on the plots in this study since 1997. The total number of cotton mice captures in 2002 and 2003 was $10.3 \%$ and $22.2 \%$, respectively, of total captures in 1997 , the year with the most captures (S.C. Loeb, unpubl. data). The decline in mouse populations was most likely a consequence of an extended period of drought that ended in 2003. Although there is probably a population threshold above which refuge availability would limit cotton mice abundance, food availability is the most likely factor limiting cotton mice populations during our study

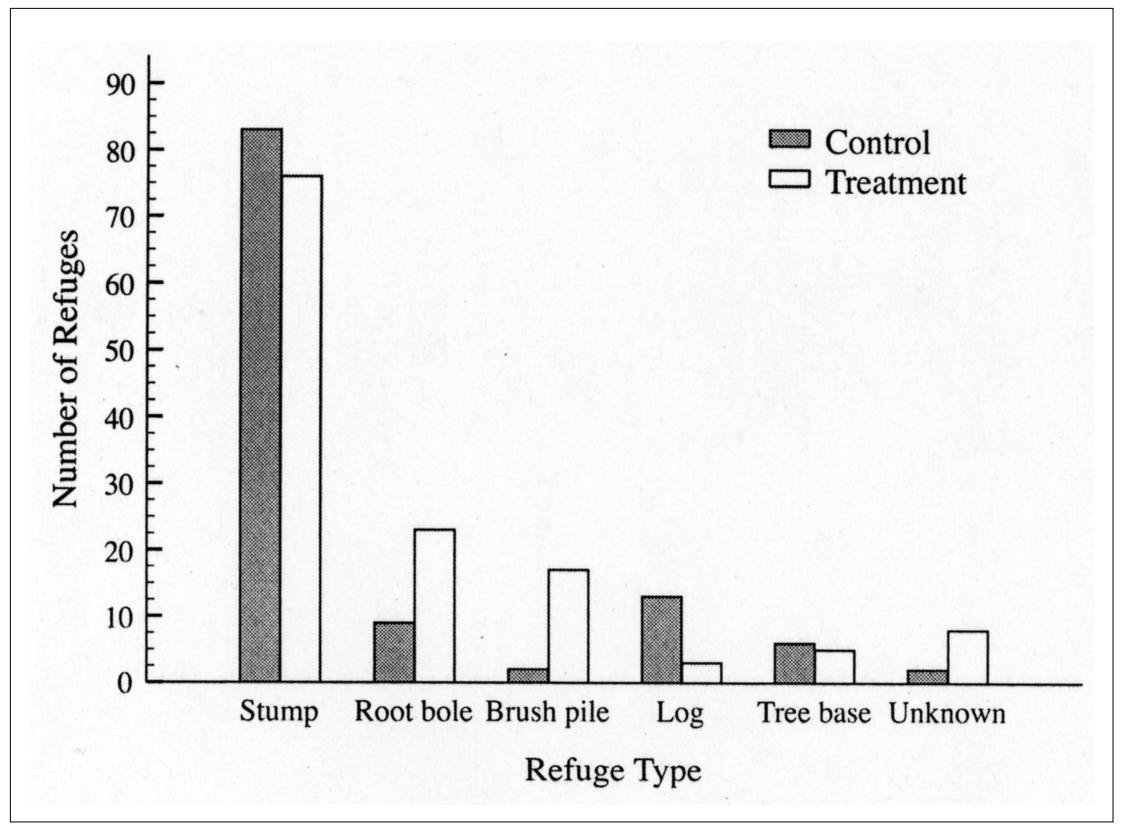

Figure 3. Number of refuges on study plots by type and treatment. 
(T.S. McCay, Colgate University, Hamilton, NY, pers. comm.). Indeed, based on a food supplementation study, Smith et al. (1984) concluded that food is a limiting factor for cotton mice under natural conditions at the Savannah River Site.

\section{Refuge fidelity}

With only three experimental plots per treatment and few mice tracked per plot over three seasons, small sample sizes may have limited our ability to detect a significant effect of season or treatment on refuge fidelity. However, within each season, differences between control and treatment plots were evident but inconsistent (Fig. 2). We expected mice on control plots to exhibit higher fidelity than mice on treatment plots because of lower woody debris volumes on control plots, but this occurred in only one out of three seasons. Our measure of refuge fidelity may not have adequately reflected the refuge-use patterns of each mouse. Further, due to small sample sizes, individual variation in refuge fidelity may have been greater than the treatment effect. Even with large sample sizes, between-individual variation and behavioral correlations across situations could obscure patterns in refuge fidelity (Bolnick et al. 2003, Sih et al. 2004). For example, consistent individual differences in boldness (e.g., bold and shy behavioral types) may influence refuge fidelity more than refuge abundance such that a shy individual may switch refuges infrequently even when refuges are abundant.

Refuge fidelity in rodents has not received much attention, despite considerable insights gained from studies of site fidelity in other taxa (e.g., roost fidelity in bats; Lewis 1995), and has primarily been studied in the context of seasonal variation. For example, Frank and Layne (1992) reported that both cotton mice and Ochrotomys nuttalli Harlan (golden mice) tended to spend more days at each refuge and switch refuges less often in the winter than the summer. Rodents often respond to cooler winter temperatures by nesting

Table 2. Parameter estimates, standard errors, and test statistics for variables of negative binomial regression model of refuge use by cotton mice. Parameter estimate indicates the direction and magnitude of the difference between two types of refuge. For example, the negative sign indicates that $\operatorname{logs}$ are only 0.68 (or $\mathrm{e}^{-0.35}$ ) times as likely as root boles to be used more than expected.

\begin{tabular}{lcccc} 
Parameter & Estimate & SE & $\chi^{2}$ & $P$ \\
\hline Vegetation cover &. &. & 4.10 & 0.043 \\
Refuge type &. &. & 9.34 & 0.053 \\
Tree base vs. $\log$ & 0.46 & 0.34 & 1.86 & 0.172 \\
Brush pile vs. tree base & -0.19 & 0.33 & 0.33 & 0.567 \\
Brush pile vs. log & 0.27 & 0.32 & 0.73 & 0.390 \\
Brush pile vs. stump & -0.10 & 0.23 & 0.18 & 0.668 \\
Tree base vs. stump & 0.09 & 0.26 & 0.13 & 0.719 \\
Log vs. stump & -0.37 & 0.24 & 2.39 & 0.123 \\
Brush pile vs. root bole & -0.45 & 0.26 & 3.09 & 0.079 \\
Tree base vs. root bole & -0.26 & 0.28 & 0.84 & 0.359 \\
Log vs. root bole & -0.35 & 0.15 & 5.52 & 0.019 \\
Stump vs. root bole & -0.35 & 0.15 & 5.52 & 0.019 \\
\hline
\end{tabular}


communally and underground (Frank and Layne 1992, Madison et al. 1984, Wolff and Hurlbutt 1982). We documented joint nesting on 5 occasions, and all occurred in winter. Less switching in the winter may suggest that refuges that are able to accommodate communal nesting and insulate against temperature fluctuations occur in low abundance. High winter fidelity could also arise from reduced activity and short periods of torpor in response to cold temperatures or low food availability (Tannenbaum and Pivorun 1984).

\section{Refuge types}

Similar to McCay (2000), we documented almost exclusive use of woody debris as refuge sites by cotton mice; $94 \%$ of refuges were associated with some type of woody debris. Stump refuges were the most used type on both control and treatment plots, but stumps were used relatively more on control plots (Fig. 3). The lower number of stump refuges used on treatment plots may have resulted from the greater use of other refuge substrates (e.g., root boles, brush piles). Alternatively, some stumps might have been destroyed by heavy equipment while trees were felled on treatment plots, and the lower use simply reflected the reduced availability of suitable stump refuges.

Treatment activities, by design, increased the abundance of logs, brush piles, and root boles on treatment plots and mice exploited the increased availability of brush pile and root bole refuges on treatment plots (Fig. 3). However, cotton mice used more log refuges on control plots, probably because the newly felled logs on treatment plots were not decayed enough to provide access as refuges or nesting cavities. Frank and Layne (1992) noted the versatile refuge selection behavior of cotton mice, which likely accounts for the different distribution of refuge types on treatment and control plots. Indeed, ephemeral refuges, such as brush piles, provided alternatives that were readily used by cotton mice. However, ephemeral refuge substrates are likely more important to refuge use and fidelity when refuges are limited (Lewis 1995).

\section{Refuge selection}

The refuge-selection analysis was based only on used sites to avoid assumptions about non-used sites (Erickson et al. 2001). Further, although we only tracked 37 mice, we identified 247 unique refuges, which was important because the refuge was the experimental unit in the analysis of refuge selection. Based on this analysis, we affirmed the importance of refuge type in refuge selection by cotton mice (Frank and Layne 1992), and identified a negative relationship between vegetation cover and refuge selection. However, logs, stumps, and trees in the refuge neighborhood were not significant predictors of refuge selection. Likewise, Wolff and Hurlbutt (1982) failed to identify any aboveground features that were related to the selection of underground refuge sites by Peromyscus.

Although nest site selection is related to protective cover in other rodents (Kalcounis-Rüppell and Millar 2002, Morzillo et al. 2003, Wagner et al. 2000), cover in the refuge neighborhood may actually 
provide ambush sites for sit-and-wait predators (Reinert et al. 1984). Cotton mice on these plots often move through open areas and do not constrain movements to maintain proximity to logs and vegetation cover (Hinkelman 2004). High surface temperatures during the day (most mice were tracked during summer) may have favored selection for refuge features that buffered environmental extremes rather than provide protective cover in the refuge neighborhood. In Florida, cotton mice use Gopher Tortoise burrows more than tree cavities because tortoise burrows provide a stable microclimate (Douglass and Layne 1978, Frank and Layne 1992). Cotton mice in our study may have selected root boles over logs and stumps because of the stability of the microclimate.

Selection for refuge type is likely related to microclimate, but certain refuge types may provide more points of escape to evade predators that enter a refuge. McCay (2000) found no differences in entrance diameter between stump refuges used by cotton mice and randomly sampled stumps, but perhaps the more relevant (and difficult to assess) attribute is the number of entrances. Decay stage may provide a surrogate measure for the number of entrances in a woody debris refuge. If so, the number of entrances may explain why cotton mice select stumps that are more highly decomposed than random stumps (McCay 2000). In Africa, Parotomys brantsii A. Smith (Brant's whistling rat), which inhabits open areas, digs many more burrow entrances than Parotomys littledalei Thomas (Littledale's whistling rat), which occupies areas of good plant cover (Jackson 2000). Given that cotton mice in our study selected refuges with less vegetation cover, the number of refuge entrances may be very important in refuge selection.

In contrast to an earlier study on SRS (McCay 2000), cotton mice in our study did not select refuges based on size. Our analysis only incorporated used refuge sites whereas McCay (2000) compared stumps and root boles used as refuges to randomly sampled stumps and root boles. Among actual refuge sites, size may not be an important criterion for refuge selection (our analysis), but size may dictate whether a potential refuge substrate is used at all (McCay 2000).

\section{Conclusions}

The limitations of our study prevented us from drawing strong conclusions about refuge fidelity in cotton mice. However, we believe that future research on refuge fidelity in rodents will yield interesting insights into habitat selection, social behavior, and population and community dynamics including predator-prey and host-parasite interactions. Nest boxes may present a cheaper alternative to radiotelemetry for studying refuge fidelity and are readily used by Peromyscus (Havelka and Millar 2000, Rose and Walke 1988). Size, number of entrances, and neighborhood vegetation cover, for example, could be easily manipulated with careful construction and placement of nest boxes.

The high association of refuges with woody debris indicates that woody debris is an important resource for cotton mice, but, as habitat generalists, 
cotton mice readily exploit a variety of refuge types. Management prescriptions that increase woody debris abundance should increase habitat quality for cotton mice by increasing the number of refuges available, which allows mice to exhibit greater selectivity in the type of refuges used. Even a small increase in the number of refuge substrates, especially root boles, may yield marked improvements in habitat quality. Further research is needed, though, to understand how refuge type and abundance interact to influence refuge use, and how food availability amplifies or negates the importance of woody debris abundance to cotton mice.

\section{Acknowledgments}

Funding was provided by Sigma Xi and the Department of Energy-Savannah River Operations Office through the USDA Forest Service Savannah River under Interagency Agreement DE-IA09-00SR22188 and the USDA Forest Service, Southern Research Station. V. Barko, D. Leput, M. Mengak, T. McCay, T. Mong, S. Zarnoch, X. Bernal, R. Strauss, and 2 anonymous reviewers provided helpful comments on an earlier version of the manuscript. We thank Charles Dachelet, Heather Ferguson, Hope Bowles, Denise Jones, and Stephanie Junker for their assistance in the field. Carolyn Wakefield, John Blake, John Kilgo, and Ed Olson provided invaluable assistance throughout the project. Trapping and handling procedures were approved by the Animal Research Committee at Clemson University under Animal Use Protocol No. 20007.

\section{Literature Cited}

Banks, P.B., K. Norrdahl, and E. Korpimäki. 2000. Nonlinearity in the predation risk of prey mobility. Proceedings of the Royal Society of London. Series B, Biological Sciences 261:49-53.

Bolnick, D.I., R. Svanbäck, J.A. Fordyce, L.H. Yang, J.M. Davis, C.D. Hulsey, and M.L. Forister. 2003. The ecology of individuals: Incidence and implications of individual specialization. American Naturalist 161:1-28.

Clark, K.L., and L.A. Durden. 2002. Parasitic arthropods of small mammals in Mississippi. Journal of Mammalogy 83:1039-1048.

Douglass, J.F., and J.N. Layne. 1978. Activity and thermoregulation of the Gopher Tortoise (Gopherus polyphemus) in southern Florida. Herpetologica 34:359-374.

Erickson, W.P., T.L. McDonald, K.G. Gerow, S. Howlin, and J.W. Kern. 2001. Statistical issues in resource selection studies with radio-marked animals, Pp. 209-242, In J.J. Millspaugh and J.M. Marzluff (Eds.). Radio-tracking and Animal Populations. Academic Press, San Diego, CA. 474 pp.

Frank, P.A., and J.N. Layne. 1992. Nests and daytime refugia of cotton mice (Peromyscus gossypinus) and golden mice (Ochrotomys nuttalli) in south-central Florida. American Midland Naturalist 127:21-30.

Hall, L.S., and M.L. Morrison. 1997. Den and relocation site characteristics and home ranges of Peromyscus truei in the White Mountains of California. Great Basin Naturalist 57:124-130.

Havelka, M.A., and J.S. Millar. 2000. Use of artificial nest sites as a function of age of litter in Peromyscus leucopus. American Midland Naturalist 144:152-158. 
Hinkelman, T.M. 2004. Behavioral responses of cotton mice (Peromyscus gossypinus) to large amounts of coarse woody debris. M.Sc. Thesis. Clemson University, Clemson, SC. 56 pp.

Jackson, T.P. 2000. Adaptation to living in an open arid environment: Lessons from the burrow structure of the two southern African whistling rats, Parotomys brantsii and $P$. littledalei. Journal of Arid Environments 46:345-355.

Kalcounis-Rüppell, M.C., and J.S. Millar. 2002. Partitioning of space, food, and time syntopic Peromyscus boylii and P. californicus. Journal of Mammalogy 83:614-625.

Keating, K.A., and S. Cherry. 2004. Use and interpretation of logistic regression in habitat-selection studies. Journal of Wildlife Management 68:774-789.

Lewis, S.E. 1995. Roost fidelity in bats: A review. Journal of Mammalogy 76:481-496.

Loeb, S.C. 1996. The role of coarse woody debris in the ecology of southeastern mammals. Pp. 108-118, In J.W. McMinn, and D.A. Crossley, Jr. (Eds.). Biodiversity and Coarse Woody Debris in Southern Forests. USDA Forest Service, Asheville, NC. General Technical Report SE-94.

Loeb, S.C. 1999. Responses of small mammals to coarse woody debris in a southeastern pine forest. Journal of Mammalogy 80:460-471.

Loeb, S.C., G.L. Chapman, and T.R. Ridley. 1999. Sampling small mammals in southeastern forests: The importance of trapping in trees. Proceedings of the Southeastern Association of Fish and Wildlife Agencies 53:415-424.

Madison, D.M., J.P. Hill, and P.E. Gleason. 1984. Seasonality in the nesting behavior of Peromyscus leucopus. American Midland Naturalist 112:201-204.

McCay, T.S. 2000. Use of woody debris by cotton mice (Peromyscus gossypinus) in a southeastern pine forest. Journal of Mammalogy 81:527-535.

McCay, T.S., J.L. Hanula, S.C. Loeb, S.M. Lohr, J.W. McMinn, and B.D. WrightMiley. 2002. The role of coarse woody debris in southeastern pine forests: Preliminary results from a large-scale experiment. Pp. 135-144, In W.F. Laudenslayer, Jr., P.J. Shea, B.E. Valentine, C.P. Weatherspoon, and T.E. Lisle (Eds.). Proceedings of the Symposium on the Ecology and Management of Dead Wood in Western Forests. USDA Forest Service, Albany, CA. General Technical Report PSW-GTR-181.

Mengak, M.T., and D.C. Guynn, Jr. 2003. Small-mammal microhabitat use on young loblolly pine regeneration areas. Forest Ecology and Management 173:309-317.

Millspaugh, J.J., R.M. Nielson, L. McDonald, J.M. Marzluff, R.A. Gitzen, C.D. Rittenhouse, M.W. Hubbard, and S.L. Sheriff. 2006. Analysis of resource selection using utilization distributions. Journal of Wildlife Management 70:384-395.

Morzillo, A.T., G.A. Feldhamer, and M.C. Nicholson. 2003. Home range and nest use of the golden mouse (Ochrotomys nuttalli) in southern Illinois. Journal of Mammalogy 84:553-560.

Norrdahl, K., and E. Korpimäki. 1998. Does mobility or sex of voles affect risk of predation by mammalian predators? Ecology 79:226-232.

Reinert, H.K., D. Cundall, and L.M. Bushar. 1984. Foraging behavior of the Timber Rattlesnake, Crotalus horridus. Copeia 4: 976-981.

Rose, R.K., and J.W. Walke. 1988. Seasonal use of nest boxes by Peromyscus and Ochrotomys in the Dismal Swamp of Virginia. American Midland Naturalist 120:258-267. 
SAS Institute, Inc. 2000. SAS OnlineDoc®, Version 8. Cary, NC.

Sih, A., A. Bell, and J.C. Johnson. 2004. Behavioral syndromes: An ecological and evolutionary overview. Trends in Ecology and Evolution 19:372-378.

Smith, M.W., W.R. Teska, and M.H. Smith. 1984. Food as a limiting factor and selective agent for genic heterozygosity in the cotton mouse Peromyscus gossypinus. American Midland Naturalist 112:110-118.

Tannenbaum, M.G., and E.B. Pivorun. 1984. Differences in daily torpor patterns among three southeastern species of Peromyscus. Journal of Comparative Physiology 154:233-236.

Wagner, D.M., G.A. Feldhamer, and J.A. Newman. 2000. Microhabitat selection by golden mice (Ochrotomys nuttalli) at arboreal nest sites. American Midland Naturalist 144:220-225.

Wolff, J.O., and B. Hurlbutt. 1982. Day refuges of Peromyscus leucopus and Peromyscus maniculatus. Journal of Mammalogy 63:666-668.

Workman, S.W., and K.W. McLeod. 1990. Vegetation of the Savannah River Site: Major community types. Savannah River Site National Environmental Park Program SRO-NERP-19:1-137. 